\title{
EFFECT OF THE CONSUMPTION OF CHOCOLATE ENRICHED WITH TRYPTOPHAN AND RESVERATROL ON BIOCHEMICAL MARKERS AND OXIDATIVE STRESS IN A HEALTHY POPULATION
}

\author{
EFECTO DEL CONSUMO DE CHOCOLATE ENRIQUECIDO CON TRIPTÓFANO \\ Y RESVERATROL SOBRE MARCADORES BIOQUÍMICOS Y DE ESTRÉS OXIDATIVO \\ EN POBLACIÓN SANA
}

\author{
Jennyfer FLÓREZ-MÉNDEZ ${ }^{1 \star}$, Jorge Yezid FLÓREZ², Elevina PÉREZ ${ }^{3}$, Mary LARES 3,4
}

Received: August 28, 2018. Approved: April 24, 2019.

\begin{abstract}
Background: Chocolate is a product with high nutritional value, of sensory characteristics accepted and preferred by the consumer, in addition to beneficial to health. Based on the benefits attributed to cocoa components, investigations have shown that chocolate consumption has been involved in the modulation of blood pressure protection, the lipid profile, the activation of platelets, and insulin sensitivity. Objective: Evaluate the effect of consuming a tablet of chocolate enriched with tryptophan present in the peanut and resveratrol contained in the peel flour and grape seed, on biochemical markers and oxidative stress in a healthy population. Methods: The study was conducted in 10 subjects aged between 20 and 40 years, who consumed daily for 21 days, a chocolate bar of $15 \mathrm{~g}$ enriched with tryptophan and resveratrol. Before starting the study and after 21 days, the participants were given weighty measures, waist, hip and blood pressure. As well as blood samples, where was analyzed: glycemia, creatinine, triglycerides, total cholesterol, HDL, LDL, VLDL, uric acid, insulin and markers of oxidative stress 8- isoprostane and catalase. The non-parametric statistical tests were applied Kruskal-Wallis for $n=10$, with a value of significance of 0.05. Results: A statistically significant decrease in insulin values and oxidative stress marker 8-isoprostane was stopped, whereas catalase values increased significantly. Conclusions: The consumption of chocolate enriched with tryptophan and resveratrol, does not alter the biochemical parameters of glycemia, creatinine, triglycerides, total cholesterol, HDL, LDL, VLDL and uric acid. But it significantly helps the decrease of insulin in blood and could have beneficial health effects related to the reduction of oxidative stress, after consuming $15 \mathrm{~g}$ of the chocolate during 21 days.
\end{abstract}

Keywords: Antioxidant, cocoa, chocolate, flavonoids, resveratrol.

Doctor degree in Food Science and Technology. CEUS Llanquihue studies center, University of Santiago of Chile (USACH), Vicente Pérez Rosales 709, Llanquihue, Chile.

2 Magister Scientiarum in higher education. Physical education Department. Healthy Faculty. University of Pamplona. Pamplona, Colombia.

3 Doctor degree in Food Science and Technology. Titular professor. Institute of Science and Technology of Food. Faculty of Science. Central University of Venezuela. Caracas, Venezuela.

4 School of Nutrition and Dietetics, Faculty of Medicine, Central University of Venezuela. Research Laboratory of Endocrinology of Military Hospital "Dr. Carlos Arvelo", San Martín, Caracas, Venezuela.

* Author of correspondence: florez.jennyfer@gmail.com 


\section{RESUMEN}

Antecedentes: el chocolate es un producto de alto valor nutricional, de características sensoriales aceptadas y preferidas por el consumidor, además de beneficioso para la salud. Basados en los beneficios atribuidos a los componentes de cacao, investigaciones han demostrado que el consumo de chocolate ha estado involucrado en la modulación de protección de la presión arterial, el perfil lipídico, la activación de las plaquetas, y la sensibilidad a la insulina. Objetivo: evaluar el efecto del consumo de una tableta de chocolate enriquecido con triptófano presente en el maní y resveratrol contendido en la harina de cáscara y semilla de uva, sobre marcadores bioquímicos y de estrés oxidativo en una población sana. Métodos: el estudio se realizó en 10 sujetos de edades comprendidas entre 20 y 40 años, quienes consumieron diariamente durante 21 días, una tableta de chocolate de $15 \mathrm{~g}$ enriquecida con triptófano y resveratrol. Antes de iniciar el estudio y pasado los 21 días, a los participantes se les tomaron medidas de peso, cintura, cadera y presión arterial. Así como muestras de sangre, donde se analizó: glicemia, creatinina, triglicéridos, colesterol total, HDL, LDL, VLDL, ácido úrico, insulina y los marcadores de estrés oxidativo 8- isoprostano y catalasa. Se aplicaron las pruebas estadísticas no paramétrica Kruskal-Wallis para $\mathrm{n}=10$, con un valor de significancia de 0,05. Resultados: se obtuvo una disminución estadísticamente significativa en los valores de insulina y del marcador de estrés oxidativo 8-isoprostano, mientras que los valores de la catalasa aumentaron significativamente. Conclusión: el consumo de chocolate enriquecido con triptófano y resveratrol, no altera los parámetros bioquímicos de glicemia, creatinina, triglicéridos, colesterol total, HDL, LDL, VLDL y ácido úrico. Pero ayuda significativamente a la disminución de Insulina en sangre y podría tener efectos beneficiosos para la salud relacionados con la disminución del estrés oxidativo, luego de consumir $15 \mathrm{~g}$ del chocolate durante 21 días.

Palabras clave: Antioxidante, cacao, chocolate, flavonoides, resveratrol.

\section{INTRODUCTION}

Generally, the chocolate is considered a treat and is not associated as an important food for nutrition. Nowadays, it can be demonstrated that chocolate is a product of high nutritional value, of sensorial characteristics accepted and preferred by the consumer, as well as being beneficial for health $(1,2)$.

Several studies have shown that cocoa and its derivatives are an exceptional source of energy and a product with a high mineral content (magnesium, copper, iron and potassium); it also contains a wide variety of active components such as flavonoids: catechins, epicatechin and proanthocyanidins (2-4).

Based on health benefits, attributed to cocoa components, researchers have shown that chocolate consumption has been involved in the reduction of cardiovascular risk through the modulation of blood pressure and lipid profile, the activation of platelets, and insulin sensivity $(5,6)$.

On the other hand, resveratrol that is defined as a polyphenol type phytoalexin (7), is a potent antioxidant, produced by more than 70 plant species in response to stress situations (8). Has been implicated with potential benefits for the metabolic syndrome, the use of energy and increased resistance (9), likewise, it helps a wide range of biological activities, including neuroprotective, anticarcinogenic, anti-ischemic, anti-aging and anti-inflammatory properties (10).

Resveratrol is abundant in the shell and grapes seeds such as viniferin (10), found in nature in the form of cis and trans isomer, being the most common form in the skin of the grape trans-resveratrol (8). Whereas shell and grape seeds are a waste of the wine industry, resveratrol can be obtained through the production of "grape flour", taking the bagasse of the red grape as the main raw material, followed by a drying and fine grinding process. Finally, this flour can be used in the formulation of different foods that you want to enrich with resveratrol.

Cocoa, in addition to antioxidant like flavonoids, contains $1.63 \%$ of tryptophan (11) which is an essential aminoacid, that is, it is obtained by means of food that contain it, since the organism does not synthesize it. This aminoacid is the precursor of serotonin that is commonly related to providing happiness and well-being within the nervous system; studies confirm that serotonin is involved with the regulation of sleep and pleasure, it has been corroborated that the presence of serotonin in the 
brain exerts various therapeutic actions within the body $(12,13)$.

Among the foods rich in tryptophan can be pointed out the chickpeas (Cicer arietinum), soy beans (Glycine max) and peanuts (Arachis hypogaea), with a total aminoacid content of $1.6 \%, 1.40 \%$ and $1.03 \%$ respectively (14).

Additional to the benefits provided by chocolate, from cocoa, this can be enhanced with the addition of other phytochemicals that provide more proven benefits for health, like tryptophan $(12,13)$ and resveratrol (10). The objective of this research was to evaluate the effect of the consumption of a tablet of chocolate enriched with tryptophan from peanuts and resveratrol present in the shell meal and grape seeds on oxidative biochemical and stress markers in a healthy population.

\section{MATERIALS AND METHODS}

\section{Composition of the chocolate tablet enriched with resveratrol and tryptophan}

Cocoa butter and liquor were used in the formulation of the cocoa tablet. Grape flour (mixture of shell and grape seeds) with a granulometry between 80 and 120 mesh, with the purpose of enriching the chocolate tablet with resveratrol, since it has been reported that one gram of grape skin presents between 0.6 and $0.75 \mathrm{mg}$ of this antioxidant (15). Likewise, peanut paste was added, since it contains $1.03 \%$ tryptophan (14).

\section{Subjects and study design}

The study was conducted in 10 subjects aged between 20 and 40 years, who consumed daily for 21 days, $15 \mathrm{~g}$ of a chocolate tablet made with peanut and peel flour and grape seed.

The exclusion criteria were: pregnant or breastfeeding women, people with significant clinical condition (kidney disease, hypertension, cardiovascular disease, diabetes, allergy or sensitivity to product ingredients, abnormal clinical laboratories), the use of medications for the treatment of: hypertension, vasodilation, erectile dysfunction, weight loss, hypercholesterolemia, use of anticoagulants and use of dietary supplements with antioxidant activity in the body.

Ethical considerations: the participants were instructed before starting to consume the chocolate; also the informed consent of each of the persons was obtained, accepting the study and the taking of samples. In addition, the investigation was approved by the ethics committee of the military Hospital "Dr. Carlos Arvelo", for complying with International Principles of Good Clinical Practice and local regulations.

\section{Measurements of weight, height, waist, hip and blood pressure}

The measurements of weight, waist, hip and blood pressure, were taken before and after the study. Blood pressure was taken at rest and sitting. The weight was taken with a scale TANITA $^{\circledR}$ UM-080 calibrated with sensitivity of $0.1 \mathrm{~kg}$ and height by means of a stadiometer with sensitivity of $0,1 \mathrm{~cm}$, reporting the average of two measurements. With the parameters of weight and height it was possible to calculate the body mass index (BMI) dividing the weight of a person in kilos between the square of its size in meters $\left(\mathrm{kg} / \mathrm{m}^{2}\right)$.

\section{Laboratory analysis}

Blood samples were taken from the fasting participants through venous puncture in tubes of ethylenediaminetetraacetic acid (EDTA) before and after 21 days of consuming the chocolate. The serum and plasma were analyzed for: Glycemia, creatinine, triglycerides, total cholesterol, HDL. cholesterol, LDL. cholesterol, VLDL. cholesterol, uric acid and insulin. The laboratory analyzes were carried out through the procedures established by Biosystems ${ }^{\circledR}$ and were carried out by the Fundae Fitlab Venezuela Diagnostic Center N.G C.A., except for the insulin analyzes that were performed under the guidelines of the Olimpo C.A Venezuela laboratory.

For the estimation of insulin sensitivity, by the HOMA model, equation 1 was used (16):

$\begin{array}{c}\text { HOMA-R } \\ \text { glycaemia }(\mathrm{mmol} / \mathrm{l}) / 22.5\end{array}$ (Equation 1$)$

The effect of chocolate consumption at the plasma level was also evaluated through the oxidative stress marker 8 -isoprostane (8-iso PGF2 $\alpha$ ), which was determined by the immunoenzymatic method (ELISA) of the commercial house Cayman Chemical, before and after consumption of the chocolate tablet for 21 days. And by means of the enzymatic oxidative stress marker, catalase, using the method described by Goth in 1991 (17). 


\section{Statistical analysis}

The statistical analysis was carried out with the Minitab 17 program, the results are shown by the average and standard deviation, in the same way he performed the non-parametric statistical test Kruskal-Wallis for $\mathrm{n}=10$, with a significance value of 0.05 .

\section{RESULTS}

Table 1 shows the water activity value (aw) and the proximal composition of the chocolate tablets enriched with resveratrol and tryptophan, supplied to patients during the intervention study.

Table 1. Water activity and proximal composition of the chocolate tablet enriched with tryptophan and resveratrol.

\begin{tabular}{|c|c|c|c|c|c|}
\hline $\mathbf{a}_{\mathbf{w}}$ & $\begin{array}{c}\text { Humidity } \\
\mathbf{( \% )}\end{array}$ & $\begin{array}{c}\text { Protein } \\
\mathbf{( \% )}\end{array}$ & $\begin{array}{c}\text { Grease } \\
\mathbf{( \% )}\end{array}$ & $\begin{array}{c}\text { Ashes } \\
\mathbf{( \% )}\end{array}$ & $\begin{array}{c}\text { CHOs* } \\
\mathbf{( \% )}\end{array}$ \\
\hline $0.33+0.06$ & $1.39+0.01$ & $23.59+1.22$ & $52.09+0.70$ & $12.33+2.56$ & 10.60 \\
\hline
\end{tabular}

$\mathrm{a}_{\mathrm{w}}$ : water activity; ${ }^{\star} \mathrm{CHOs}$ : Total carbohydrates by difference. Each value is the average of $n=3+S D$.

In Table 1 it can be seen that the chocolate tablet enriched with resveratrol and tryptophan, has low water activity and low humidity. While the content of protein, fat and ash is high.

\section{Measurements of Body Mass Index (BMI), weight, waist, hip and blood pressure}

Table 2 shows the results of the measurements of BMI, weight, waist, hip and blood pressure of the patients before and after the consumption of chocolate enriched with tryptophan and resveratrol.

Table 2. Measurements of BMI, weight, waist, hip and blood pressure of healthy patients who were given daily $15 \mathrm{~g}$ of a chocolate tablet enriched with tryptophan and resveratrol for 21 days.

\begin{tabular}{|l|c|c|c|}
\hline \multirow{2}{*}{ Parameter } & Day zero & Day 21 & $\begin{array}{c}\text { Level of } \\
\text { significance } \\
\text { (P=0.05) }\end{array}$ \\
\cline { 2 - 3 } & ${ }^{\star} \overline{\times}$ & $\overline{\times}$ & 0.824 \\
\hline BMI $\left(\mathrm{kg} / \mathrm{m}^{2}\right)^{\star \star}$ & $21.9 \pm 1.73$ & $21.8 \pm 1.70$ & 0.970 \\
\hline Weight $(\mathrm{kg})$ & $59.8 \pm 8.16$ & $59.5 \pm 7.67$ & 0.821 \\
\hline Waist $(\mathrm{cm})$ & $72.9 \pm 5.96$ & $72.7 \pm 5.78$ & 0.850 \\
\hline Hip $(\mathrm{cm})$ & $87.6 \pm 8.41$ & $87.3 \pm 8.06$ & 0.545 \\
\hline Systolic BP $(\mathrm{mmHg})^{\star \star \star}$ & $108.9 \pm 9.83$ & $112 \pm 6.32$ & 0.940 \\
\hline Diastolic BP $(\mathrm{mmHg})^{\star \star \star}$ & $71.9 \pm 6.37$ & $71 \pm 5.68$ & 0.96 \\
\hline
\end{tabular}

${ }^{\star} \bar{X}=$ Arithmetic measure. Each value is the average, $n=10 .{ }^{\star \star} \mathrm{BMI}$ : Body Mass Index. ${ }^{\star \star \star} \mathrm{BP}$ : Blood pressure. The results obtained were statistically evaluated with the non-parametric Kruskal- Wallis test with a level of significance $(\mathrm{P})$ of $5 \%$.
In the results obtained it can be observed that there is no statistically significant variation during chocolate consumption, for any of the parameters evaluated.

\section{Blood chemistry}

Table 3 shows the results obtained for the laboratory analyzes, of the participants evaluated before and after the consumption of $15 \mathrm{~g}$ of chocolate enriched with tryptophan and resveratrol for 21 days.

Table 3. Results of the blood chemistry of healthy patients who were given daily $15 \mathrm{~g}$ of a chocolate tablet enriched with tryptophan and resveratrol for 21 days.

\begin{tabular}{|l|c|c|c|}
\hline \multicolumn{1}{|c|}{ Parameter } & Day zero & Day 21 & $\begin{array}{c}\text { Level of } \\
\text { significance } \\
\text { (P=0.05) }\end{array}$ \\
\cline { 2 - 4 } & $* \overline{\times}$ & $\overline{\times}$ & 0.112 \\
\hline Glycemia (mg/dL) & $74.1 \pm 6.36$ & $77.8 \pm 4.98$ & 0.028 \\
\hline Insulin (mg/dL) & $7.06 \pm 3.05$ & $4.4 \pm 1.71$ & 0.104 \\
\hline Creatinine (mg/dL) & $0.65 \pm 0.10$ & $0.57 \pm 0.08$ & 0.364 \\
\hline $\begin{array}{l}\text { Triglycerides } \\
\text { (mg/dL) }\end{array}$ & $115.5 \pm 28.28$ & $106.7 \pm 20.70$ & 0.089 \\
\hline $\begin{array}{l}\text { Total cholesterol } \\
\text { (mg/dL) }\end{array}$ & $143.9 \pm 16.17$ & $127.2 \pm 28.68$ & 0.940 \\
\hline $\begin{array}{l}\text { HDL cholesterol } \\
\text { (mg/dL) }\end{array}$ & $40 \pm 4.42$ & $39.9 \pm 3.72$ & 0.059 \\
\hline $\begin{array}{l}\text { LDL cholesterol } \\
\text { (mg/dL) }\end{array}$ & $80.8 \pm 11.88$ & $65.96 \pm 24.01$ & 0.089 \\
\hline $\begin{array}{l}\text { VLDL cholesterol } \\
\text { (mg/dL) }\end{array}$ & $28.78 \pm 3.23$ & $25.44 \pm 5.73$ & 0.910 \\
\hline Uric acid (mg/dL) & $4.13 \pm 0.45$ & $4.09 \pm 0.45$ & -- \\
\hline HOMA & $1.30 \pm 0.57$ & $0.86 \pm 0.36$ & \\
\hline
\end{tabular}

${ }^{\star} \bar{x}=$ Arithmetic measure. Each value is the average $\pm S D, n=10$. The results obtained were statistically evaluated with the non-parametric Kruskal-Wallis test with a significance level (P) of 5\%.

The results obtained do not indicate any level of representative statistical significance except for insulin, a parameter in which there was a decrease in the value after chocolate consumption. In the same way, a decrease in the HOMA factor is observed.

It should be noted that all volunteers were within the normal ranges for each of the biochemical parameters evaluated before and after chocolate consumption.

\section{Markers of oxidative stress}

Table 4 shows results obtained for the markers of oxidative stress 8-isoprostane and catalase, before and after the consumption of chocolate enriched with tryptophan and resveratrol. 
Table 4. Results of oxidative stress markers 8-isoprostane ( 8 -iso PGF2 $\alpha$ ) and catalase, in healthy patients who were given daily $15 \mathrm{~g}$ of a chocolate tablet enriched with tryptophan and resveratrol for 21 days.

\begin{tabular}{|l|c|c|c|}
\hline \multirow{2}{*}{$\begin{array}{c}\text { Oxidative } \\
\text { stress marker }\end{array}$} & Day zero & Day 21 & \begin{tabular}{c} 
Level of \\
significance \\
\cline { 2 - 4 }$(\boldsymbol{p}=\mathbf{0 . 0 5})$
\end{tabular} \\
\cline { 2 - 4 } $\begin{array}{l}\text { 8-isoprostane } \\
(\mathrm{pg} / \mathrm{mL})\end{array}$ & $128.31 \pm 55.88$ & $82.66 \pm 43.30$ & 0.005 \\
\hline Catalase (kU/L) & $77.59 \pm 22.72$ & $112.94 \pm 45.17$ & 0.032 \\
\hline
\end{tabular}

${ }^{\star} \bar{x}=$ Arithmetic measure. Each value is the average $\pm S D, n=10$. The results obtained were statistically evaluated with the non-parametric Kruskal- Wallis test with a significance level (P) of 5\%.

The results indicate that there is a statistically significant decrease between the 8-isoprostane values before and after the treatment, since level of significance lees than $\alpha(0.05)$ was obtained. In the same way, a statistically significant increase in catalase values is observed after consuming chocolate for 21 days.

\section{DISCUSSION}

\section{Composition of chocolate tablet enriched with resveratrol and tryptophan}

The low moisture content (1.39\%) observed in tablet 1 is close to that obtained for dark chocolate (70\% cocoa liquor) Venezuelan (18). Similarly, the low $\mathrm{a}_{\mathrm{w}}(0.33)$, indicates a stable storage life of this product, and places it in the classification of low moisture non-perishable foods.

The results observed in terms of the percentage of fat obtained $(52.09 \%)$, are similar to the results obtained by the Soxhlet method, where $56.21 \%$ of fat was reported in chocolate (19). It should be noted that cocoa is an important source of protein and fat; since it has been achieved that the protein content of fermented, dried and roasted cocoa beans is around $12 \%$, while the fat content is approximately $45 \%(20)$.

\section{Measurements of Body Mass Index (BMI), weight, waist, hip and blood pressure}

Chocolate contains a significant amount of fat, so it should be considered a highly energetic food, this fact can relate to an increase in body weight; however, it can be observed (Table 2) that there were no significant variations in this parameter, since the average weight of the participants before starting the study was $59.8 \mathrm{~kg}$, and once the study concluded the average of this parameter was 59.5 $\mathrm{kg}$, these results coinciding with different clinical trials, (21-22) which have not reported an increase in body weight when chocolate is consumed in moderate quantities, on the contrary they have shown a reduction of weight at the expense of fat.

Regarding blood pressure, the results obtained (Table 2) in this study indicate that initially the participants presented, on average, the systolic blood pressure at $108.9 \mathrm{mmHg}$ and the diastolic blood pressure at $71.9 \mathrm{mmHg}$, finding a slight variation once the investigation was completed, where the participants presented, on average, 112 $\mathrm{mmHg}$ for systolic blood pressure, and $71 \mathrm{mmHg}$ for diastolic blood pressure. These results are not similar to those derived from other investigations, where it has been possible to reduce the systolic and diastolic pressure, after consuming chocolate in moderated amounts.

In one of the studies conducted, the researchers observed a decrease in blood pressure of 14 obese individuals, after they consumed $20 \mathrm{~g}$ of dark chocolate rich in polyphenols (23). Another study reported a decrease in systolic and diastolic pressure, when 15 adult individuals with mild hypertension consumed $100 \mathrm{~g}$ of chocolate for 14 days, although these results were not maintained after two days without consuming chocolate (24). A decrease in blood pressure of hypertensive people with low glucose tolerance has also been found, by providing $100 \mathrm{~g}$ of chocolate for 15 days (22).

\section{Biochemical markers}

According to the criteria of the American Diabetes Association (ADA), the fasting glycemia values were within a normal range $(<100 \mathrm{mg} / \mathrm{dL})$ both before and after the study, and no statistically significant differences were observed in the values of glycemia, of the individuals studied, before and after chocolate consumption.

The values of insulin presented a statistically significant decrease before and after the study, finding these values initially at $7.06 \pm 3.05 \mathrm{mg} / \mathrm{dL}$ and at $4.40 \pm 1.71 \mathrm{mg} / \mathrm{dL}$ once the study was completed.

The results of HOMA in the normal population range from 0.93 to 2.51 and in diabetics from 2.91 to 12.87 (25), so it can be considered that the population studied had normal values of HOMA, $1.30 \pm 0.86$ before the intervention and $0.86 \pm 0.36$ after consumption of chocolate, observing a slight decrease after consumption; higher values could 
be indicative of insulin resistance in daily practice in these patients.

Different investigators have observed that insulin resistance is reduced after a diet with flavonoid-rich chocolate for 15 days (22-26). On the other hand, in hypertensive patients with glucose intolerance, flavonoid-rich dark chocolate improved endothelial function, and insulin sensitivity (22-26).

A close relation has been established between obesity - particularly abdominal obesity - and insulin resistance and type 2 diabetes mellitus (27). In these diseases dark chocolate consumption has been shown to reduce insulin resistance and, thus, attenuate fasting or postprandial glycemia (28).

This study showed that dark chocolate rich in polyphenols decreases and improves insulin sensitivity in healthy people. These findings indicate that dark chocolate may exert a protective action on the vascular endothelium also improving insulin sensitivity (22).

It is important to note that the variation of insulin or HOMA, could be attributed to the effect of polyphenols (Flavan-3-ol, procyanidins and resveratrol) present in chocolate. A study reported an independent inverse relationship between daily chocolate consumption and levels of insulin, HOMA and liver enzymes in adults, suggesting that chocolate consumption may improve liver enzymes and protect against insulin resistance, a well-established risk factor for cardiometabolic disorders (29).

Results obtained in a research have shown that cocoa flavanols are able to modulate carbohydrate and lipid metabolism in liver cells, improving insulin sensitivity and glucose tolerance in a situation of insulin resistance and diabetes (30).

In Table 3, the values of the lipid profile measurements (total cholesterol, triglycerides, HDL-cholesterol, LDL-cholesterol and VLDL cholesterol) can also be observed, from the patients evaluated, before and after the start of the intervention study. No statistically significant differences were observed in these values, before and after chocolate consumption.

Despite not finding statistically significant differences in the lipid profile, a slight decrease in total cholesterol was noted, since from 115.50 $\pm 28.28 \mathrm{mg} / \mathrm{dL}$ it decrease to $106.70 \pm 20.70 \mathrm{mg} /$ $\mathrm{dL}$ after the consumption of chocolate enriched with tryptophan and resveratrol. This is because the cocoa butter, predominant in dark chocolate, is a vegetable fat without cholesterol that contains on average $33 \%$ of monounsaturated oleic acid and $33 \%$ of stearic acid (5).

The HDL cholesterol did not present a statistically significant variation either, since before the investigation an approximate value of 40.00 $\pm 4.42 \mathrm{mg} / \mathrm{dL}$ was registered, and after the study time the average HDL cholesterol value was 39.00 $\pm 3.72 \mathrm{mg} / \mathrm{dL}$. While LDL cholesterol decrease slightly, from $80.80 \pm 11.88 \mathrm{mg} / \mathrm{dL}$ to $65.96 \pm 24.01$ during the investigation; however, this decrease was not significant. This is because, the stearic acid present in cocoa butter does not lower high density lipoprotein (HDL), not does it increase LDL or total cholesterol (5).

However, in contrast to the results obtained, several studies point to the beneficial effect of dark chocolate consumption on the lipid profile. A study conducted in hypertensive patients, where the daily consumption was $100 \mathrm{~g}$ of dark chocolate rich in flavonoids for more than 2 weeks, produced a significant reduction of $12 \%$ in serum levels of total cholesterol and LDL (22). A study in Japan showed that in patients with hypercholesterolemia, consumption of flavanol-rich dark chocolate lowers plasma levels of LDL and oxidized LDL cholesterol, while increasing serum HDL concentrations (31).

It is necessary to emphasize that grape flour not only has resveratrol, also incorporate different phytochemicals, in a wide proportion polyphenols, which can regulate lipids metabolism because one of the most studied beneficial properties of polyphenols is its ability to improve the lipid profile (32), several studies corroborate that polyphenols are capable of attenuating onset and progression of atherosclerosis, due to their ability to attenuate the oxidation of LDL because they are capable to increase in concentration of HDL cholesterol in plasma, and also to inhibit the proliferation of vascular smooth muscle (33-34), this disease is mainly characterized by the progressive obstruction of the arteries as a consequence of the accumulation of lipids in arterial wall (35), which could explain the decrease, although not significant, of lipid profile markers obtained in this study.

Regarding the values of triglycerides, no statistically significant difference was found between the values of this parameter before and after consumption of chocolate, since before starting the investigation the approximate value of triglycerides 
was $115.50 \pm 28.28 \mathrm{mg} / \mathrm{dL}$ and after completing the intervention study, the mean value of triglycerides in the participants was $106.70 \pm 20.70 \mathrm{~m} / \mathrm{dL}$. These results do not resemble other studies where there was an improvement in triglycerides levels, since clinical studies report that, epicatechin (polyphenol: flavonoid present in chocolate) significantly reduces the concentrations of triglycerides in the blood, both fasting as a postprandial (36).

Several estudies reported a significant inverse association between chocolate intake and cardiometabolic disorders (37) the same results were reflected when supplying $100 \mathrm{~g}$ of chocolate during 15 days to 19 hypertensive adults with low glucose tolerance (22).

Similarly, an increase in serum HDL cholesterol was observed when 45 healthy, non-smoking volunteers received $75 \mathrm{~g}$ of dark chocolate for 45 weeks (38). So, moderate consumption of dark chocolate or cocoa-rich products has been associated with better lipid profile: higher HDL together with lower LDL and total cholesterol.

However, other research has shown that, in the short term, chocolate lowers LDL by approximately $6 \mathrm{mg} / \mathrm{dL}$ without significantly altering "good" cholesterol (HDL) (39); adjusting these results with those obtained in the preset study, although there was no significant difference between the values of LDL before and after the consumption of chocolate, it could be observed that if there was a decrease in the same, it also occurs for the values of VLDL but not with ample margin.

One study states that caffeine and theobromine (substances present in chocolate) are a group of water-soluble components that prevent the oxidation of uric acid and have stimulating properties in the nervous system (40). However, in this study no significant change was observed regarding the levels of uric acid before and after chocolate consumption. Since the participants initially presented a mean uric acid value of $4.13 \pm 0.45 \mathrm{mg} / \mathrm{dL}$ and after the study this value remained at $4.09 \pm 0.45 \mathrm{mg} / \mathrm{dL}$, these values being within the normal range.

\section{Oxidative stress markers}

Numerous in vitro and in vivo studies show that cocoa and its flavonoids exert an antioxidant effect by directly neutralizing free radicals (41-42) and activating antioxidant enzymes (43). Thus, consumption of cocoa and dark chocolate increase plasma antioxidant capacity in animals and humans (44-45) and vasodilation (41).

The 8-isoprostane oxidative stress marker has also been evaluated, concluding that dark chocolate inhibits platelet function by reducing oxidative stress in smokers (46).

Similarly, the antioxidant effect of dark chocolate components was confirmed after administering 20 $\mathrm{g}$ daily of this for 1 week to 12 metabolically healthy subjects, when determining the marker of oxidative stress 8-isoprostane, the study showed a statistically decrease significant $(p \leq 0.05)$, possibly due to the effect of polyphenols present in dark chocolate (5).

On the other hand, hydrogen peroxide is an important reactive species of oxygen, is produced endogenously and historically has been perceived as deleterious promoting oxidative damage to cells. Well known for its role in the metabolization of hydrogen peroxide in water and oxygen, catalase can interact with cellular detoxification systems and prevents cell damage by eliminating hydrogen peroxide (47).

Table 4 shows the results obtained by measuring the marker of enzymatic oxidative stress, catalase, before and after the consumption of chocolate enriched with tryptophan and resveratrol. Getting a statistically significant increase, from $77.59 \pm 22.72$ $\mathrm{kU} / \mathrm{L}$ to $112.94 \pm 45.17 \mathrm{kU} / \mathrm{L}$.

Catalase protects cells and tissues against oxidative damage and can also influence the mechanisms of signal transduction; studies suggest that acatalasemic individuals (that is, with very low catalase activity) have a higher risk for the development of diabetes, and corroborate that catalase-depleted mice develop and obese, pre-diabetic phenotype and provide convincing evidence of that catalase (or its products) is integral to metabolic regulation (48):

The results obtained in relation to oxidative stress markers correlate very well, while one decrease significantly (8-isoprotane), the other increase in the same way (catalase), this is because 8 -isoprostane arises as a derivative compound of lipid peroxidation capable of indicating oxidative stress, a decrease that indicates a significant decrease in oxidative stress in blood, while catalase protects cells and tissues against oxidative damage, an increase that helps in maintaining the oxidant/ antioxidant balance in the body; all of the above related to the consumption of formulated chocolate. 


\section{CONCLUSION}

The consumption of chocolate enriched with tryptophan and resveratrol does not alter the biochemical parameters of glycemia, creatinine, triglycerides, total cholesterol, HDL, LDL, VLDL and uric acid. But it helps significantly to the decrease of insulin in blood, after consuming $15 \mathrm{~g}$ of chocolate for 21 days, which makes it a functional food. As for the antioxidant activity, the formulated chocolate could have the beneficial health effects related to the reduction of oxidative stress, such as the prevention of diabetes, metabolic syndrome and insulin resistance.

In this study it was possible to corroborate that there is a statistically significant decrease between the values of 8-isoprostane, since before the treatment patients had values around $128.55 \pm$ $55.88 \mathrm{pg} / \mathrm{mL}$ and after treatment the values were reduced to approximately $82.66 \pm 43.30 \mathrm{pg} / \mathrm{mL}$, suggesting these results a possible modulation of oxidative stress.

\section{CONFLICTS OF INTEREST}

The authors declare no conflicts of interest.

\section{ACKNOWLEDGMENTS}

To POMAR companies, for the supply of one of the raw materials. A KiriKire chocolates, for the realization of the tablets. To the Institute of Food Science and Technology, to the School of Chemistry of the Central University of Venezuela, to the quality laboratory of the National Institute of Agricultural Research, to the Center of Quality Research of POLAR companies, to the Institute of Advance Studies and to the Hospital Military "Carlos Arvelo", for the collaboration provided in the realization of the different laboratory analyzes.

\section{AUTHOR'S CONTRIBUTIONS}

Conceived of the presented idea and designed the analysis: Jennyfer Flórez-Méndez, Elevina Perez y Mary Lares. Collected the data: Jennyfer Flórez-Méndez y Jorge Yezid Flórez. Performed the analysis: Jennyfer Flórez-Méndez y Jorge Yezid Flórez. Supervised the findings of this work: Elevina Perez y Mary Lares. Wrote the manuscript: Jennyfer Flórez-Méndez y Jorge Yezid Flórez with support from Elevina Perez y Mary Lares.

\section{REFERENCES}

1. Cooper, K. A., Donovan, J. L., Waterhouse, A. L., \& Williamson, G. Cocoa and health: a decade of research. Brit J Nutr. 2008. 99(1), 1-11

2. Lares M, Pérez E. Chapter 5. Types of chocolate and their nutritional value - chocolate as a functional food. In: Chocolate: Cocoa Byproducts Technology, Rheology, Styling and Nutrition. Ed. Pérez E, NOVA Publisher. 2014.

3. PérezE, Álvarez C, Medina O. Chapter 2. Cocoa phytochemicals: Chemical structure, changes during processing and uses. In: The uses of cocoa and cupuaçu byproducts in industry, health, and gastronomy. Ed. Perez E, NOVA Science Publisher. 2018.

4. Méndez A, Sívoli L, León M, Pérez E. Chapter 4. Cocoa bean husk as an ingredient in the development of products for phenylketonuric consumers. In: The uses of cocoa and cupuaçu byproducts in industry, health, and gastronomy. Ed. Pérez E, NOVA Science Publisher. 2018.

5. Lares M, Pérez E. Effect of the dark chocolate consumption on some markers of oxidative stress, endothelial dysfunction and inflammation of a healthy population. EC Nutrition 2017; 9(2):78-87.

6. Lares M, Miskiewicz A, Suárez O. Chapter 5, Cocoa and chocolate, health benefits. In: The uses of cocoa and cupuaçu byproducts in industry, health, and gastronomy. Ed. Pérez E, NOVA Science Publisher. 2018.

7. Holthoff J, Woodling K, Doerge D, Burns S, Hinson J, Mayeux P. Resveratrol, a dietary polyphenolic phytoalexin, is a functional scavenger of peroxynitrite. Biochem Pharmacol 2010; 80(8):1260-1265.

8. Burns J, Yokota T, Ashihara H, Lean M, Crozier A. Plant foods and herbal sources of resveratrol. J Agric. Food Chem. 2002; 50(11): 3337-3340.

9. Hurst W, Glinski J, Miller K, Apgar J, Davey M, Stuart D. Survey of the trans-resveratrol and trans-piceid content of cocoa-containing and chocolate products. J Agric. Food Chem. 2008; 56(18): 8374-8378.

10. Shetty A. Promise of resveratrol for easing status epilepticus and epilepsy. Pharmacol. Ther. 2011; 131(3): 269-286.

11. Bertazzo A, Comai S, Brunato Ll, Zancato M, Costa C. The content of protein and non-protein (free and protein-bound) tryptophan in Theobroma cacao beans. Food Chem. 2011; 124(1): 93-96.

12. Paredes S, Terrón M, Cubero J, Valero V, Barriga C, Reiter R, Rodríguez A. Tryptophan increases nocturnal rest and affects melatonin and serotonin serum levels in old ringdove. Physiol Behav. 2007; 90(4): 576-582.

13. Cubero J. Tryptophan, melatonin and activity/inactivity rhythms in diurnal animals and lactating infants. Phagocytosis and oxidative metabolism. University of Extremadura. Spain. 2004. ISBN: 84-7723-660-7:34.

14. Comai S, Bertazzo A, Bailoni L, Zancato M, Costa C, Allegri G. Protein and non-protein (free and protein-bound) tryptophan in legume seeds. Food Chem. 2007; 103(2): 657-661.

15. Counet C, Callemien D, Collin S. Chocolate and cocoa: New sources of trans-resveratrol and trans-piceid. Food Chem. 2006; 98(4): 649-657.

16. Contreras F, Lares M, Magaldi L, María A, Velasco M. Determination of insulin sensitivity by the Mathematical Model of Homeostasis Assessment Model (HOMA) in type 2 diabetic and hypertensive patients. Rev Latinoam Hiperte 2008; 3(6): 201-204.

17. Goth L. A simple method for determination of serum catalase activity and revision of reference range. Clin Chim Acta.1991; 196:143-152.

18. Fernández V, Yee A, Sulbarán B, Peña J. Antioxidant activity and polyphenol content in Venezuelan commercial chocolates. Magazine of the Faculty of Agronomy 2014; 31(1): 129-144. 
19. Cala TC, Herrera Y. Evaluation of the effect of cocoa processing on the content of polyphenols and their antioxidant activity. [Trabajo de pregarado]. [Bucaramanga, Colombia]: Industrial University of Santander: 2008. 91 p.

20. Álvarez, C., Pérez, E., Cros, E., Lares, M., Assemat, S., Boulanger, R., \& Davrieux, F. The use of near infrared spectroscopy to determine the fat, caffeine, theobromine and $(-)$-epicatechin contents in unfermented and sun-dried beans of Criollo cocoa. JNIRS. 2012. 20(2), 307-315.

21. GuY, Hurst W, Stuart D, Lambert J. Inhibition of key digestive enzymes by cocoa extracts and procyanidins. J Agric. Food Chem. 2011; 59(10): 5305- 5311.

22. Grassi D, Lippi C, Necozione S, Desideri G, Ferri C. Short-term administration of dark chocolate is followed by a significant increase in insulin sensitivity and a decrease in blood pressure in healthy persons. Am J Clin Nutr. 2005; 81(3): 611- 614.

23. Almoosawi S, Fyfe L, Ho C, Al-Dujaili E. The effect of polyphenol-rich dark chocolate on fasting capillary whole blood glucose, total cholesterol, blood pressure and glucocorti-coids in healthy overweight and obese subjects. Br J Nutr. 2010; 103: 842-850.

24. Taubert D, Berkels R, Roesen R, Klauss W. Chocolate and blood pressure in elderly individuals with isolated systolic hypertension. JAMA 2003; 290: 1029-1030.

25. Lares M, Castro J, Obregón O. Determination of insulin sensitivity by the mathematical model of homeostasis (HOMA). Salus Militiae 2002; 27(2): 32-34.

26. Grassi D, Desideri G, Necozione S, Lippi C, Casale R, Properzi G, Blumberg J, Ferri C. Blood pressure is reduced and insulin sensitivity increased in glucose-interolerant hypertensive subjects after 15 days of consuming high-polyphenol dark choco-late. J Nutr. 2008; 138: 1671-1676.

27. Farag, Youssef MK, and Mahmoud R. Gaballa. Diabesity: an overview of a rising epidemic. Nephrol Dial Transplant. 2010: 28-35.

28. Isomaa $\mathrm{B}^{1}$, Almgren P, Tuomi T, Forsén B, Lahti K, Nissén M, et al. Cardiovascular morbidity and mortality associated with the metabolic syndrome. Diabetes Care. 2001: 683-689.

29. Alkerwi, A. A., Sauvageot, N., Crichton, G. E., Elias, M. F., \& Stranges, S. Daily chocolate consumption is inversely associated with insulin resistance and liver enzymes in the Observation of Cardiovascular Risk Factors in Luxembourg study. Brit J Nutr. 2016. 115(9), 1661-1668.

30. Cordero Herrera, I. Mechanisms of action of cocoa flavanols in liver cells during insulin resistance and diabetes: study in cell cultures and in experimental animals. [Doctoral Work] Complutense University of Madrid. 2015.

31. Baba S, Natsume M, Yasuda A, Nakamura Y, Tamura T, Osakabe N, Kanegae M, Kondo K. Plasma LDL and HDL cholesterol and oxidized LDL concentrations are altered in normo-and hypercholesterolemic humans after intake of different levels of cocoa powder. J Nutr. 2007; 137(6): 1436-1441.

32. Aviram M, Rosenblat M. Macrophage-mediated oxidation of extracellular low density lipoprotein requires an initial binding of the lipoprotein to its receptor. J Lipid Res 1994; 35: 385-398.

33. Abe R, Beckett J, Abe R, Nixon A, Rochier A, Yamashita N, Sumpio B. Olive Oil Polyphenol Oleuropein Inhibits Smooth
Muscle Cell Proliferation. Eur J Vasc Endovasc Surg 2011; 41: 814-820.

34. Osakabe N, Baba S, Yasuda A, Iwamoto T, Kamiyama M, Takizawa T, Itakura H, Kondo K. Daily cocoa intake reduces the susceptibility of low-density lipoprotein to oxidation as demonstrated in healthy human volunteers. Free Radic Res 2001; 34: 93-99.

35. Abu-Amsha R, Croft KD, Puddey IB, Proudfoot JM, Beilin LJ. Phenolic content of various beverages determines the extent of inhibition of human serum and low-density lipoprotein oxida- tion in vitro: identification and mechanism of action of some cinnamic acid derivatives from red wine. Clin Sci (Lond) 1996; 91: 449-458.

36. Kurlandsky S, Stote K. Cardioprotective effects of chocolate and almond consumption in healthy women. Nutr Res 2006; 26: $509-516$.

37. Buitrago-Lopez, A., Sanderson, J., Johnson, L., Warnakula, S., Wood, A., Di Angelantonio, E., \& Franco, O. H. Chocolate consumption and cardiometabolic disorders: systematic review and meta-analysis. BMJ. 2011; 1-8.

38. Mursu J, Voutilainen S, Nurmi T, Rissanen T, Virtanen J, Kaikkonen J, Nyyssonen K, Salonen J. Dark chocolate consumption increases HDL cholesterol concentration and chocolate fatty acids may inhibit lipid peroxidation in healthy humans. Free Radic Biol Med. 2004; 37(9): 1351-1359.

39. Barone J, Roberts H. Caffeine consumption. Food Chem. Toxicol. 1996; 34:1119-1129.

40. Zoumas, B, Kreiser, R, Martin, R. Theobromine and caffeine content of chocolate products. J Food Sci. 1980. 45(2). 314-316.

41. Corti R, Flammer A, Hollenberg N, Lüscher T. Cocoa and cardiovascular health. Circulation 2009; 119(10): 1433-1441.

42. Lamuela R, Romero A, Andrés C, Tornero A. Review: health effects of cocoa flavonoids. Revista de Agroquímica y Tecnología de Alimentos 2005; 11(3): 159-176.

43. Ramiro E, Casadesús G, Lee H, ZhuX, McShea A, Perry G, et al. Neuroprotective effect of cocoa flavonids on in vitro oxidative stress. Eur J Nutr. 2009; 48(1): 54-61.

44. Vinson J, Proch J, Bose P, Muchler S, Taffera P, Shuta D, Agbor G. Chocolate is a powerful ex vivo and in vivo antioxidant, an antiatherosclerotic agent in an animal model, and a significant contributor to antioxidants in the European and American diets. J Agric. Food Chem. 2006; 54(21): 8071-8076.

45. Baba S, Osakabe N, Natsume M, Yasuda A, Takizawa T, Nakamura T, Terao J. Cocoa powder enhances the level of antioxidative activity in rat plasma. Br J Nutr. 2000; 84(05): 673-680.

46. Carnevale R, Loffredo L, Pignatelli P, Nocella C, Bartimoccia S, Di Santo S, Violi F. Dark chocolate inhibits platelet isoprostanes via NOX2 down-regulation in smokers. J. Thromb. Haemost. 2012; 10(1): 125-132.

47. Lubos E, Loscalzo J, Handy D. Glutathione peroxidase-1 in health and disease: from molecular mechanisms to therapeutic opportunities. Antioxid Redox Signal. 2011; 15(7): 1957-1997.

48. Heit C, Marshall S, Singh S, Yu X, Charkoftaki G, Zhao H, Vasiliou, V. Catalase deletion promotes prediabetic phenotype in mice. Free Radic Biol Med. 2017; 103: 48-56. 